\title{
Compulsive Scribblers. A Semiotic Challenge Based on the Works of Kunizo Matsumoto
}

\section{Bruno Surace}

The challenge faced in this paper is to attempt to formulate a semiotic analysis around the works of Kunizo Matsumoto, Japanese exponent of Art Brut affected by mental illness. Interfacing with the textualities produced by Matsumoto, thousands upon thousands of pages generated by a form of compulsive graphomania, means questioning some of the premises of general semiotics and of its approach to art: the concept of "autonomy of the text", the issue of the author's intentionality, the relationship between communication and signification, the conception of artistic discourse as a rhetorical form, the ambiguous existence of idiolect, the interpolation of the borders between symbolism and iconism. These issues will be subjected to examination in a dissertation which, before embarking on a specifically visual-plastic analysis, will try to delineate the relationship between mental pathology and artistic production in a semiotic regime which can in some way help extrapolate the domains of sense in the works of Matsumoto, providing a possible epistemological pattern to account for the manner in which irregular art is semiotized. In order to substantiate the questions raised above, at the centre of the paper there will, in fact, be a discussion of the possibilities of a signifier for its own sake, released from Saussure's dual conception of sign, which will lead to a new definition of artistic discourse as a "breaking free from the code" based on the metabole of repetition, a rhetorical device able to describe "lateral" forms of art, such as those produced under an obsessive psychic regime, within a sort of fractal semiotics open to objective analysis. Starting from a hermeneutic declination of Davidson's "principle of charity", this may produce semiosic results with reference to the text beyond the psychopathological specifics - which are of fundamental relevance also in pre-semiotic areas - of the subject who elaborated it, freeing Matsumoto's work from the yolk of an interpretation burdened by biological determinism.

KEYWORDS Kunizo Matsumoto, graphomania, Art Brut, mental illness, signifier

Therein lay hidden and threatening, although unknown to him, a future teeming with horrid professors of semiotics and brilliant avant-garde poets.

Juan Rodolfo Wilcock, The Temple of Iconoclasts, 1972

\section{Compulsive graphomania}

When visiting the abcd collection of Art Brut in Montreuil (France), one may happen to stumble across some rather strange manufacts which cannot be defined by a specific artistic criterion and 
which therefore may often themselves be initiators of a new or separate 'canon'. One would not expect otherwise from a museum dedicated by its very name to the display of art that is unrefined, if not often manifestly "ugly" or unaesthetic, nevertheless one always remains somewhat perplexed on finding oneself in front of works like those of Kunizo Matsumoto, located in the remotest corner of the collection. Sheet upon sheet, exercise book pages or parts of calendars, literally overflowing with calligraphic attempts which are indecipherable even by the most cultured of Japanese, constantly reiterated in a sort of coherent - while enigmatic - variation on a theme, composed of crammed spaces and empty areas, in a plastic exercise that appears anything but random. It thus seems, in conclusion, that one has come up against an unknown language, endowed with its own grammar, if not even with its own alphabet for which no Rosetta Stone exists.

This suspicion, which for the semiotic scholar constitutes one of the biggest and most stimulating challenges conceivable, arises precisely from the repetitive nature - going well beyond obsession - of Matsumoto's work: such cast-iron reiteration must surely mean something. Secondly, but equally important, the search for meta-codes within the texts in question cannot but constitute a succulent enigma, starting perhaps from the phemic fragments referring to known symbolic configurations which may in some way aid decoding. This method may however seem rather difficult to those unversed in the Japanese system of ideograms and, anyway, is to be discarded to date on the grounds of the relevant literature which is unanimous in sustaining that as far as Matsumoto is concerned, references to the Japanese ideographic code stop at the imitation of the plastic formants; it may thus be necessary to resort to the age-old idiolectal hypothesis, postulating that the artist's calligraphic exercise consists in the execution of a language of his own. In the third and final analysis the situation is further complicated when it emerges that the artist suffers from a psychic disturbance. The dimension of mental unease therefore enters the equation and the semiotic challenge becomes even broader: whether or not to take into account the clinical peculiarities of his condition (crucial to his work, as can be seen in the rare film segments which portray Matsumoto in the act of writing), or entrust oneself slavishly to the principle of textual autonomy at the risk of overinterpretation. And even if one were to choose the second alternative, how does one proceed seeing that the compulsive nature of the works, one of the first stylemes the observer notes, is undeniably tied to its creator's psychopathological condition? That mysterious repetition is symptomatic of a burden rather than a gift, as those affected by obsessive-compulsive disorders well know. In this regard Freud, correlating the concept of repetition compulsion to instinctual drives, writes that:

A drive is an urge inherent in organic life to restore an earlier state of things which the living entity has been obliged to abandon, under the pressure of external disturbing forces; [...] it is a kind of organic elasticity, or, to put it another way, the expression of the inertia inherent in organic life (Freud SE 18: 36).

Yet this condition would seem to give rise to a complete artistic discourse, not easily approachable by means of the customary interpretative heuristics. An interesting dilemma.

\section{Breaking free from the code}

It is by now pretty much the norm (Danto 1981, Bohem 2009, Simongini 2012), to regard artistic discourse, in an aesthetological context, as a rhetorical exercise on a par with other discursive regimes, as ascertained by Alexander Gottlieb Baumgarten:

Sense perception may lie at the centre of Baumgarten's aesthetics only as far as rhetoric allows it to be recognized as capable of an autonomous cognitive strategy of perfection. For 
Baumgarten, the aesthetic argument takes place in the articulation of a connection of sense perceptions, and the rhetoric illustrates the structural rules whereby occurs the perfectioning of sensual knowledge towards which all aesthetics aims (Tedesco 2008: 135).

In other words, art has its codes and, even though it may be executed precisely in an attempt to break free from them, in fact all it does is create new ones, generating rhetoric. It therefore appears that avoiding the code is almost impossible, seeing that not even artistic discourse - to which this task is usually delegated - is able to achieve it, yet Matsumoto's work seems to re-introduce this form of unexpected communicative motility. Indeed in this writer's texts the figure of repetition, which is a rhetorical styleme sedimented in centuries of practice, appears to be unhinged from any persuasive intention, and manifests itself rather as a sort of tic. To all effects the use of repetition by the artist in question would not seem to assume the value of an actual metabola (as the figures of repetition in the $\mu$ group are called), but rather to encapsulate metataxis, metasememes, metalogisms and metaplasms at the same time, displacing their individual specificity in favour of repetitio as such. This potentially infinite movement really represents the decline of any form of rhetoric in that it does not pursue any perlocutionary objective, but solely its own perpetuation. Having established this, reiteration for its own sake, not subjected to any teleological regime (not finalised), can scarcely be considered a semiotic process. Banally: what does it mean? One must be careful not to dismiss the issue as trivial, for if one were to settle the question by declaring that Matsumoto writes (or draws?) solely because driven to do so by his compulsion, then one would be eliminating the alternative domain from the analytical horizon, thereby impoverishing in a Saussurian sense the event of any trace of semiotic valence. Yet one could even deny the artist any form of planning or intention, while sustaining that his work nevertheless proves to be invested with sense since it is independent from its creator (the principle of textual autonomy), but once again one would risk losing one's sense of direction, debasing textualities which could (and perhaps, ethically, should) also be read as reflections precisely of whoever conceived them. The solution in this extremely delicate (but certainly not unique) case would appear to be that - generally suited to the hermeneutics of all forms of art - of remaining firmly anchored to the protasis, making the potential condition the interpretative horizon of reference, moreover according it the hermeneutic principle of charity which contemplates at the same time from the most 'pragmatic [dimension] of explicability to the epistemic [dimension] of truth' (Longato 1999: 150); in other words, if something can signify, then it does.

\section{Insignificant signifiers}

In order to proceed further without transcending the epistemologies of reference - that is, perhaps by sustaining - rather impressionistically - that it amounts to finally pure art, namely, art that has been purified of the burden of signification - it is here necessary to refer to the theoretical formulations of Jacques Lacan, first of all those associated with the so-called primacy of the signifier or, going back to Slavoj Žižek, the Master-Signifier. In fact, owing to the psychopathological conditions that cause it, the aesthetic valence of Matsumoto's work is to be sought above all in the actio, that is to say, in the act of the very production of the signifier. And here perhaps occurs the brutalisation (in a positive sense) of the artistic discourse, realised in 'a signifier available without its signified, or before it, so to speak, as in the case of the color blue announcing [...] the adduction in the order of the dynamics of the body itself' (Lyotard 2011: 80). The linear manifestation of the text (to put it in Eco's terms) is thus the very fulcrum of Matsumoto's aesthetics in that it is the execution in praesentia of a pre-narrative - if not altogether pre-semiotic - agency, which is actualized in the deturpation of the sheet of paper, brochure or calendar. Regarding the writers, in fact - but the concept may well be 
applied here too - Dagostino states that 'for the traditional graphomaniac deturpation has aesthetic valence' (Dagostino 2006: 72) and, indeed, this resides in the externalization of one's very being as a semiotic animal, in leaving a sign which is a sign of oneself. Partially similar is the operation which Marinetti was performing when arranging ideophones on his pages:

The blank page is no longer a neutral space, a support for writing, but theatrum and lusus, a synesthetic field of action, the possible vehicle for a visualization of the vital fluxes in which consciousness is immersed (Picciau 2007; 114).

The sign thus becomes a modality for contact between Matsumoto's mind and the external world, as happens for every other individual, but acquires an artistic dimension when it becomes the expression of a semiosic diversity, precisely due to its serial nature which distinguishes it from the improvised doodle that everyone will produce during a moment of boredom. It does not therefore appear particularly useful to approach the issue in the positivist spirit which in 1903 was delivering sentences like: 'The genesis of graphomania is to be sought in the very nature of delirium' (Giornale di psicopatologia e neuropsichiatria, vol.31). In the charitable perspective cited above, it would rather seem necessary to look into the specifics of the plane of expression in Matsumoto's work, carefully separating the content one might attribute it ex-post - perhaps playing at tracing the codes as John Nash used to do with United States periodicals - from the plastic peculiarities which are instead characteristic of the Japanese artist's style (we can now so define it).

\section{Fractal Semiotics}

Matsumoto's art therefore constitutes art brut (rough art, raw art, or, in the words of Roger Cardinal, outsider art) on account of its incessant, compulsive nature, as if it were a sort of tic. Nevertheless the exercise of replication is not lacking in variations, which once again fit in with the artist's basic graphomania, concealing themselves in the thick web of signs woven from text to text. On a structural level the semiotics of Matsumoto's work cannot but conform to this fractal geometry, that is, to the substantial absence of change in scale of the work which determines a figure 'that is repeated infinitely with the same characteristics in all dimensions' (Canonico e Rossi 2007, 598). Ultimately the author's is a causal, controlled randomness, hence by examining different portions of different texts one can as a general result obtain roughly the same effect, given the substantial absence of content of the individual ideograms. Having said this, it does not follow that his work can be measured with formulae such as that proposed by mathematician George Birkhoff in 1930, according to which by dividing $\mathrm{O}$ (Order) and C (Complexity) one obtains M (Aesthetic beauty). Rather, one can appropriate the aesthetic dimension of the fractal concept understood as 'geometry of chaos [and] transformation of a simple phenomenon into a marvellous design, based on the fraction which recurs in its segments' (Intilla 2006: 128).

Nonetheless Matsumoto's proto-ideograms are not exactly born ex-novo, like improvised scribbles, but are the fruit of a laborious, constant, maniacal search for sources which draw from disparate subjects, for the most part connected with Kabuki theatre (歌舞伎). It is not easy to trace the motivations underlying this preference, yet one must acknowledge that statistically the brochures picked up by the artist around Osaka principally refer to this theme. One will therefore notice in his work the copy, albeit subtle or difficult to decipher, of ideograms pertaining to this sphere yet, as previously stated, it would not seem particularly productive to use this contingency as a relevant principle for interpretation. Certainly, the more intrepid student of hermeneutics could sustain that the glyphs on the sheets of paper, with their graphematic references to the centuries-old Japanese dramatic arts, recall the topoi of the Kabuki in their spaces and movements, perhaps producing results that are as 
fascinating as those which topicalize the Holy Scriptures in a UFOlogical key. However, if even the few biographies that exist of Matsumoto tell us that in his "School for the Disabled" he preferred to spend all his time reciting roles in "Japanese historical dramas", the link between theatre and writing is not to be traced to some sort of common significance. He would seem rather to have developed a passion-obsession for Kabuki which leads him to collect whatever his mind can most tangibly connect to this ethereal semantic sphere, and that is the signs that refer to it. In this sense, his is truly meta-writing, in no way interested in describing or narrating a propensity but only in establishing it, continually pinning it down, substantiating it in a primigenial form (that of existing prior to signifying) which is completed in the act of sign production. What re-emerges therefore is the critical issue of the primacy of the signifier which signifies itself before anything else, assuming the nature of a paradoxical, oxymoric, solid but elusive meta-sign, which perhaps provides an explanation of Matsumoto's ranting activity.

\section{Glyphs, alphabets, and monoplane semiotics}

Matsumoto's work is therefore the fruit of a pre-semiotic semiotics, in that it does not apply itself to translating anything. It is not a question of translation, but rather of conlation, as the movement and perpetration of significant cells. This said, it is inevitable to consider how Japanese writing effected by means of kanji (嫨字, sinograms in Japan) lends itself particularly well to this type of exercise since, 'besides possessing an acoustic image, it is also equipped with a visual image, the ideogram' (Marchianò 1992: 102). This alphabetic peculiarity probably lies at the base of the approach adopted by this artist who, according to the biography cited in footnote 1 , has never learnt to read, despite manifesting from an early age a spasmodic interest in writing. This would corroborate the hypothesis whereby his fascination with ideograms is due to their decodification as iconic units, or perhaps more precisely as units characterised by semi-symbolism, as described by Greimas with regard to monoplane semiotics:

A type of "language" characterized not, as in the case of symbolism in the narrow sense ("interpretable monoplane semiotics", formal languages), by the conformity of isolated elements, but by conformity between categories (according to Hjelmslev: paradigmatic classes of units which can be interchanged at a certain point in the syntagmatic chain) (Fabbri e Sbisà 2001: 242).

In fact, Matsumoto's semiotics would appear to be of the monoplane variety on account of its totally metalinguistic character, which does nothing except try to substantiate itself as a kind of graphematic ouroboros. He takes the symbols or the images of the Japanese linguistic system and transfers them onto his supports, favouring some rather than others because they are visually or semantically connected to his past experiences, creating a work that appears motivated by a pantagruelic tautology: "I imprint because I imprint". It seems difficult to think that he could do the same with the graphemes of the Latin alphabet, inasmuch as this last is composed of totally symbolic units which rarely convey autonomous meanings in their singularity, but rather accomplish meaning in the execution of combinatorial art. The key to Matsumoto's signifier lies in the iconological contamination of the glyph kanji, in which he presumably recognizes a subject content which he systematically strips bare in favour of the celebration of the phemic categories which underlie it. For Matsumoto, the glyph is the code which enables him to break free from the code itself:

With the glyph, we are beyond semiotics, and beyond ontology. Once even perception (of an object or an event) can be articulated as socially dimensioned (along with feeling, emo- 
tion, experience, etc.), it escapes categorization as either individual or social, ontological or semiotic (Martinot, 2006: 222).

Who does he do this for? Perhaps for himself, perhaps for no one, like Antonio Moresco in his Lettere a nessuno (Letters to no one) which he felt the need (or maybe the urge) to write despite not having anyone to write them to.

\section{Physiology and alternative}

Introducing compulsive urgency into the act of writing constitutes a not insignificant semiotic issue. If we are in fact dealing with an impelling drive to communicate, then this falls fully within the scope of phenomena which this discipline is able to analyze with its instruments, but if instead this need belongs to the sphere of physiology, the semiosic contingency is reduced to a collateral effect of an obligatory process, that is, there is no alternative. Indeed, a dictionary definition of graphomania reads:

the continuous - in some subjects manic - tendency to write on everything, in a pathological form. For some subjects, however, it may also be a "liberation", an unconscious need, not pathological (Pigliacampo 2009: 162).

In other words, the movement from the domain of possibility to that of necessity (obvious right from the title of the exhibition organised by Yukiko Koide, The Art of Necessity: Personal and Practical Creative Urgency, which also includes Matsumoto's work) implies a derailment from signedness (segnicità) to fabrility (fabrilità), to use Cirese's categories for distinguishing between execution invested with sense and that merely aiming at existence (1984), or from sign to function, to recall a similar concept of Leroi-Gourhan's. It is thus necessary to differentiate between pathological compulsion and communicative emergency in order to avoid falling into the 'temptation to tendential pansemioticism' (Ponzio 1976: 160) when dealing with the issue, throwing into the same epistemological cauldron the outpourings on the walls of toilets in a service station - a rash operation, semi-rational, but soundly semiotic - and a sneeze - an operation which can at most signify in a semeiotic setting. This having been explicated, a huge problem arises as to the relationship between art and mental illness, tending precisely towards the definition of the confines between semiosis and physiology which, however, must also consider how:

(a) the very concept of fabrility turns out to be somewhat critical since "every transformation of space can be read as a significant" (Greimas 1991: 130);

(b) the images produced by the mentally ill may be read as "a collection of pathognomic details" (Tosatti 1997: 36) and therefore possess a semiotic substrate;

(c) the principle of charity previously cited may be regarded as a "reasonable act of faith" (Baruchello 2002:34) whereby it is worth conceding Matsumoto's work a hermeneutic "chance" rather than not doing so;

(d) inevitably sense can be traced in work which is the fruit of a psychopathology once this has been "given to the world", that is, rendered to a community of readers who signify it in some way.

\section{Plastic stylemes in Matsumoto}

Having explained the caution needed, it is possible to approach Matsumoto's work trying to apply to it a general, plastic semiotic analysis which can ascertain the necessary presence of stylemes in order to be able to speak of an underlying grammar. 

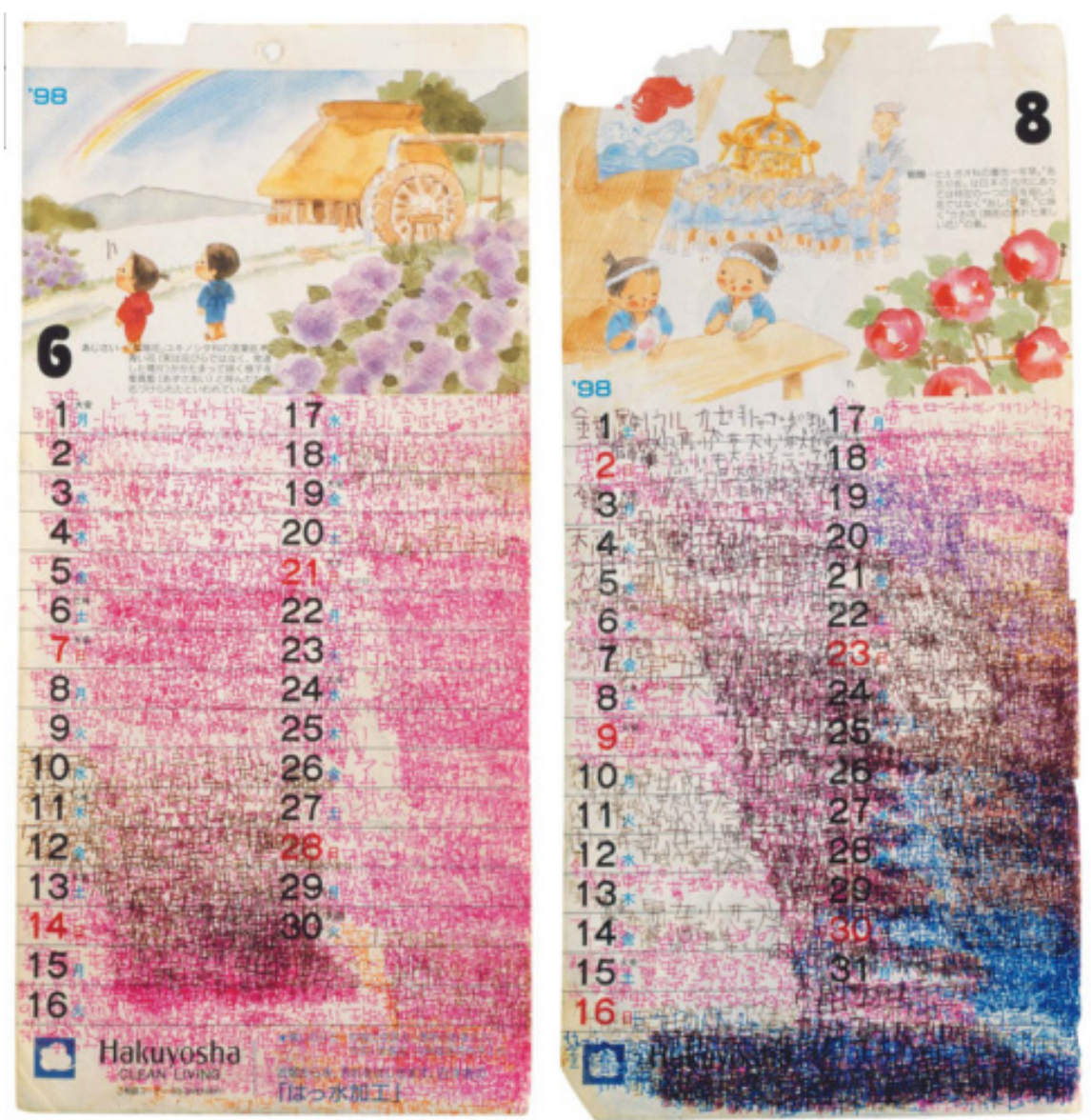

Fig. 1. Kunizo Matsumoto, untitled (1715-1716) @ ART BRUT - collection abcd, Montreuil.

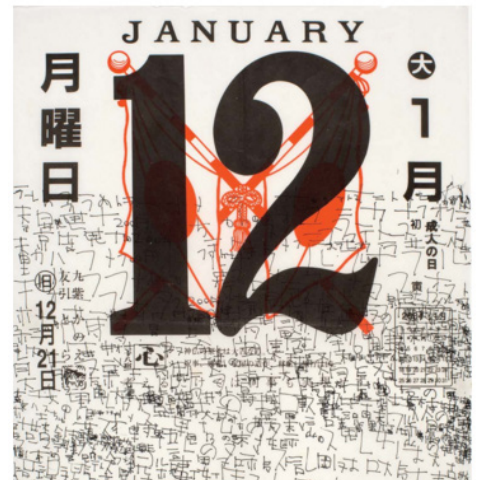

Fig. 2. Kunizo Matsumoto, untitled (1554) @ ART BRUT - collection abcd, Montreuil.

From a topological perspective there is no doubt that the texts in question aim to saturate the writing surface, where full spaces prevail over empty spaces to an overwhelming extent, to signify a sort of irreversible branding of the support by the artist. Nevertheless one notices, in certain series, the expression of a kind of iconic "respect" towards the semioticized area. In the case of the calendars presenting decorative frills (see fig. 1), for example, these frills are never marked by the glyphs but are accurately avoided instead, as if to honour the intrinsic harmony of the support. On the contrary, as far as concerns the calendars without images (fig. 2) but showing the dates in cubital characters, the artist invades the space already occupied, writing over them, but interrupting his calligraphic outburst when he comes to the more visible paratextual ideograms situated at the top; nevertheless it should be highlighted that this occurs only in certain series of works, while in others the page is regarded as a "signable" surface in its entirety, as in fig. 3 , where the only differences to be found in the support are the absence of the red design behind the central number and the utilization of a blue font. The page is therefore treated with a certain semiotic reverence out of respect for the signs which, in order of size but also of meaningfulness, already inhabit 
it. Instead, the remaining copious flow of signs which pours forth from Matsumoto's hands floods every possible available area, almost as if - from the point of view proposed here - the artist were accepting a sort of invitation from the empty spaces asking, inasmuch as they reflect the full spaces, to be filled. This dynamic of rational and organized filling is typical of certain obsessive psychopathological states, as in the case of serial collectors of objects (who identify forms of cosmos in the chaos they construct), and is probably the psychological root at the base of this semiotic operation. One must add, moreover, that the inner spaces of the written surface also contain certain distinctive traits: in fig. 2 and fig. 3 it can clearly be seen how the bottom left-hand corner presents a form of dilation which seems to balance the overrunning of the top left- and right-hand corner, in favour of a kind of re-balancing of symmetry (that is, as appears evident with regard to obsessive-compulsive disorders, of harmony). A similar operation also appears in the ensemble in fig. 4, where the writing surface is no longer the page of a calendar but a white sheet with the drawing of a geisha at the bottom. In this case, too, we find very crammed writing on certain areas of the surface (typically the upper areas or those surrounding the printed graphics) juxtaposed with a dilatation; furthermore here, too, a sort of respect seems to be shown towards the area previously signed, in this case by an icon.

This reverence towards the support can again be noted on a chromatic level. In the case of fig. 2 the black and white of the calendar page (with the exception of the red design at the centre which, perhaps because it is manifestly an "intruder" on the page, is not taken into consideration in terms of the global eurythmics) is maintained intact by the sole utilization of a black pen, just as instead the colours of the illustration in fig. 1 are unimaginatively reproduced in the polychromatic structure of the writing. One can even, with closer attention, venture the hypothesis of coherence in relation to the regimes of chromatic quantity: the blocks of ideograms in different colours are not in fact all the same size, and seem to copy the amount of colour present in the picture in the upper margin of the page. If this were so, one would find oneself before an extraordinary and refined example of intersemiotic translation within Matsumoto's work, whereby the image is translated into a form of writing which retains its semi-symbolic properties and isotopic-chromatic references, creating a not insignificant semiotic short-circuit.

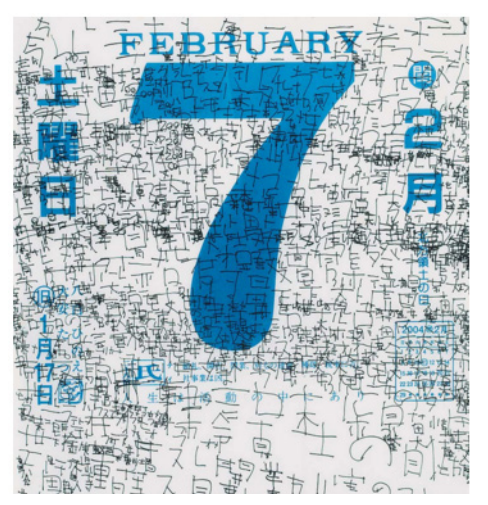

Fig. 3. Kunizo Matsumoto, untitled (1557) (C) ART BRUT - collection abcd, Montreuil.

Finally, on an eidetic level the argument is more complex and potentially insoluble. If forms and lines are present in Matsumoto's work, these refer solely to the segments of graphemes and to the individuation of blocks composed of these. As far as the first possibility is concerned, it is somewhat complicated to infer, above all for those who (like the author of this paper) cannot read Japanese. Nevertheless, at a basic level of comparison it can be noted how the artist's writing is essentially square or rectangular, that is, devoid of that calligraphic gracefulness adopted instead by whoever wishes to impress upon the signs s/he produces a sort of visual musicality (or a "choreography of letters" as in the case of the Tunisian artist Nia Mahdaoui). This datum is rather relevant as, having ascertained that Matsumoto himself perceives the act of writing as a rhythmic, expressive exercise, 
the absence of graphic "spangles" may be read as a kind of loyalty towards the sign as sign, or rather towards the signifier as such, the beauty of which lies in the structure which constitutes it more than in the trappings applied to it. Any type of adornment appears banned from Matsumoto's approach - another indication of rawness as a form of authentic beauty - which manifests itself in its crudity. As far as concerns the lines which form the blocks of characters, these are defined instead solely by chromatic change in fig. 1, which does nothing except identify the rectangular portions within the rectangle that is the page, and are totally absent in fig. 2 , in harmony with the monochromatic quality of the work in toto.

Now, given Matsumoto's psychopathology, it is evident that many (if not all) the analytical considerations advanced above are the result of an enactment of unconscious cognitive and compulsive processes. Specifically, the correlation between Matsumoto's psychopathology and his artwork can be traced in the following semio-stylistic dimensions:

A tendency to repetition and to the standardization of his work which goes beyond the established concept of series, given its endurance in time. If one looks at Claude Monet's series, for example, the series composed of thirty paintings of the Cathedral in Rouen, one can identify a progression from the beginning to the end, where the seriality is significant in the measure in which it expresses a change. On the contrary, Matsumoto's work is, even within its reiterated production of minimal differences, always the same in concept, and as such compulsive.

The manic urge to collect anything and everything related to the Kabuki theatre; this hoarding disorder (disposophobia) of Matsumoto's spills over into his work, where the subject of Kabuki is in some measure rendered through a proto-code, which results in its transposition from an objectual to a graphematic dimension.

The continuation of the act of writing even once the chosen surface has been completely covered; Matsumoto, in fact, continues to write in the air, as it were, as if to create an imaginary dance.

The continuation of the act of writing late into the night (beyond the preset time for artistic production), on the calendar of the restaurant where he works during the day. His relatives are not permitted to touch these works, which is symptomatic of a mania for possession.

All the features hitherto mentioned may be examined in the context of diverse clinical frameworks (obsessive compulsive disorder first of all), but also in the light of approaches which outline their artistic and semiotic valence. This discussion has focused on the latter, with the aim of suggesting that Matsumoto's work may justifiably be seen as anything but an exercise in senseless, simple or demented scribbling but, on the contrary, constitutes a form of communication - perhaps authentically idiolectal - which is extremely stimulating due to its essentially deconstructionist nature.
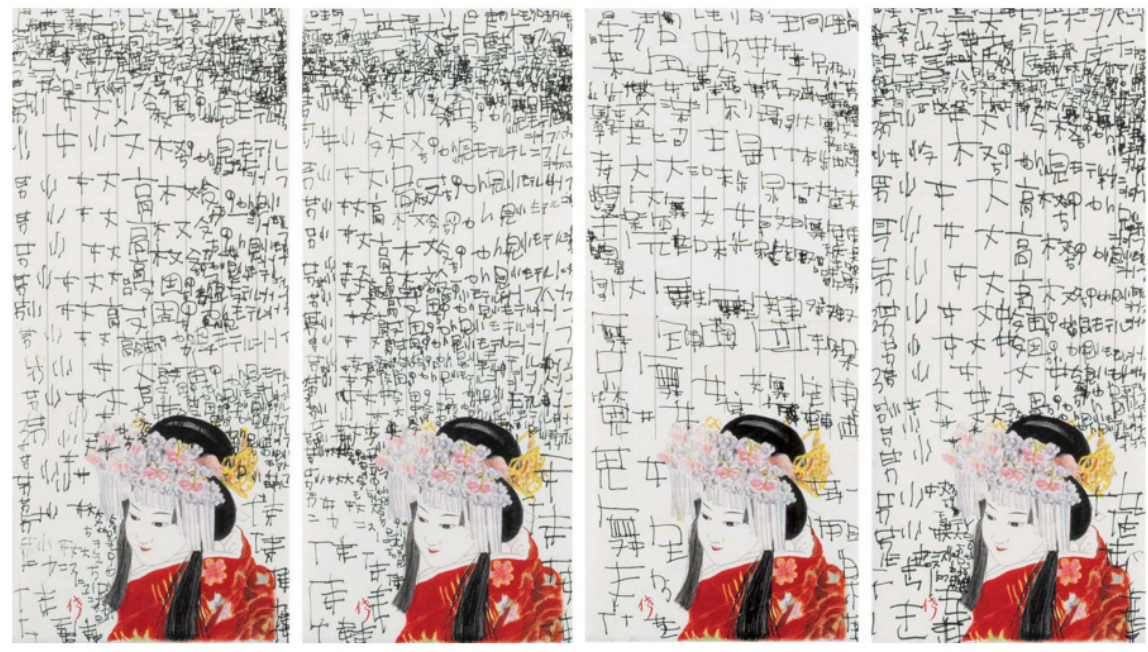

Fig. 4. Kunizo Matsumoto, ensemble untitled (1774) (C) ART BRUT - collection abcd, Montreuil. 


\section{Semiotics and interstice}

To conclude this brief dissertation on compulsive graphomania as a form of art, on the possibility of a mutilated sign in which only the signifier exists and on the problems connected to the analysis of works produced by mentally ill subjects, one cannot but dwell on the liminal nature of the entire issue. We have in fact crossed the threshold into gray zones of semiotics, where the debate is necessarily uncertain, interfacing with the unknown. Nevertheless this is not stretching the discipline or its epistemic horizons, nor would it seem that the theoretical operations carried out have denatured the consolidated methodologies belonging to the subject. On the contrary, it is felt that if there must be a direction, this should be devoted to a constant, measured push towards the frontiers of semiotics, which coincide with the frontiers of sense in that interstitial space which exists between sense and semiosic vacuum. In this context, Matsumoto's work appears rather indicative in explicating the gap between mental image and its enactment by means of writing. It is precisely to this gap, that vacuum of communicability where the difference between the semiotic and the non-semiotic lies, that we have turned in the attempt to comprehend its morphology in conditions that are often not contemplated or relegated to the clinic, exactly like those of psychopathology. If, in fact, semiotics deals with alternatives, that is, with manifestations of diversity, then the products of a psychically disordered person or of a healthy person constitute terrains that are analyzable in the same measure, clearly starting from the premises that can or cannot be advanced case by case as regards the influences that the pathology may have had on the generation of the text.

\section{NOTES}

1. My thanks go to the abcd collection in Montreuil for their cooperation and the kindness shown me in granting me the possibility to reproduce certain works present in their collection.

2. We owe the concept of Art Brut to Jean Dubuffet, a twentieth-century French artist who postulated a form of art which "rather than ugly, was raw, rough and tough, dry and blunt, anti-artistic, anti-poetic and anti-cultural" (Spirito 2007: 159). It is therefore an expressive activity which, to a trans-Dadaist extent, aims at the destruction of the rule in favour of a conceptual discussion which calls the beautiful into question not by contrasting it with the ugly (cfr. Rosenkranz 1853) but by juxtaposing Art Brut as an absolute category which does not admit contradiction inasmuch as it is the manifestation of a kind of Truth-beyond-art.

3. Biography of Kunizo Matsumoto, drawn from his page on the website of the Collection de l'Art Brut in Lausanne (www.artbrut.ch): "Kunizo Matsumoto was born in Osaka, Japan. He worked as a dishwasher in a Chinese restaurant run by his relatives. At the same time, from 1985 to 1988 he attended a creative workshop for the mentally handicapped, where he started to become interested in calligraphy. Matsumoto was fascinated by the notes that the staff at the establishment wrote in little notebooks and attempted to reproduce them, even though he had never learnt to write. Subsequently, Kunizo Matsumoto developed his own personal written work, which he has continued since 1995 in an artistic workshop for the mentally handicapped. Using a brush, he obsessively copies ideograms from the numerous types of printed matter (calendars, tourist guides and catalogues of painting exhibitions) which he collects and piles up in his room. Very frequently he transforms them or invents new ideograms from them. His favourite subject is Kabuki. He gathers together all documents concerning this form of traditional Japanese dramatic art, as well as everything dealing with the tea ceremony. He then studies these texts in meticulous detail before launching himself into writing, feverishly covering entire pages of exercise books, 
calendars and other supports. He never goes out without taking a plastic bag, as well as his backpack and belt-bag, filled with printed documents on which he draws".

4. "It is, rather, what is sometimes called "idiolect". It is the set of rules that exist only in a given individual's mind and that guide his/her linguistic perfomance. [...] Chomsky phrases this issue slightly differently in his more recent work. There he contrasts "I-language" and "E-language". I-language or "internalized language" is idiolect" (Colm Hogan 2000: 287).

5. In this regard we recommend the clip "Kunizo Matsumoto (ар-брют каллиграфия)", which can be found at the follwing link: https://www.youtube.com/watch?v=FCObpSVe4ls (last consulted 03/11/2015).

6. Cf. McGinn and Sanderson 2005.

7. Original quotation: "La percezione sensibile può stare al centro dell'estetica di Baumgarten solo in quanto la retorica permette di riconoscerla capace di un'autonoma strategia conoscitiva di perfezionamento. L'argomentazione estetica ha luogo per Baumgarten nell'articolazione di un nesso di percezioni sensibili, e la retorica illustra le regole strutturali per il cui tramite avviene il perfezionamento della conoscenza sensibile cui tutta intera l'estetica è finalizzata". My translation in the text.

8. As will be better explained further on, the issue concerns the debate between the possible and the necessary, and that is, between alternative and obligation. If the former in fact applies primarily to the discipline of semiotics, since it implies a range of differences from which sense can originate, the latter - being one-dimensional - cannot directly be situated within the discipline but rather interfaces with the horizons of the "hard" natural sciences. A sneeze, for example, contains little that is semiotic, as it is the unequivocal effect of a physiological or environmental trigger event which generally cannot be resisted. If instead the sneeze, in special circumstances, becomes the manifestation of an alternative (for example, a sneeze which forms part of an avant-garde musician's artistic repertoire, or a vehemently loud sneeze produced in an attempt to distract a burglar who is trying to break into a house, and so on), then it can be connected to the subject of semiotics.

9. "According to Davidson one can assume as evidence the speaker's intention to assert a truth, that is, to affirm a belief which he truly professes. The possibility of such an assumption is based on the nature of language, that is, on the intention of speaker and listener to optimize comprehension. It is not a question of linguistic sharing or mutual affiliation to a jargon, but of the instance of comprehension which actuates the communication [...]. This communication develops around a variously defined but univocally mentioned postulate. It is the principle of charity [...]. In other words, thanks to the principle of interpretative charity we optimize others' systems of belief in order to safeguard interpretation and hence comprehension between speakers " (Boniolo and Vidali 2003: 28-29). My translation.

10. Original quotation: "pragmatica dell'esplicabilità a quella epistemica della verità". My translation in the text.

11. Original quotation: "Per il tradizionale grafomane deturpare ha una valenza estetica". My translation in the text.

12. Original quotation: "La pagina bianca non è più uno spazio neutro, un supporto per la scrittura, ma theatrum e lusus, un campo d'azione sinestetica, il tramite possibile di una visualizzazione dei flussi vitali in cui è immersa la coscienza". My translation in the text.

13. Original quotation: "La genesi della grafomania è da ricercare nella natura stessa del delirio". My translation in the text.

14. Original quotation: "che si ripete all'infinito con le medesime caratteristiche ad ogni livello di grandezza". My translation in the text.

15. Cf. Sala and Cappellato 2004, about the relationship between art and fractals. 
16. Original quotation: “[...] geometria del caos [e] trasformazione di un fenomeno semplice in un meraviglioso disegno, basato sulla frazione ricorrente dei suoi segmenti". My translation in the text.

17. Original quotation: "[...] oltre a possedere un'immagine acustica, è dotata anche di un'immagine visiva, l'ideogramma". My translation in the text.

18. But also to that in the catalogue of the exhibition devoted to Art Brut in Prague in 2006; cf. Decharme, Safarova and Zemankova 2006.

19. Original quotation: "un tipo di "linguaggio" caratterizzato non, come nel caso del simbolismo in senso stretto (le "semiotiche monoplane interpretabili", i linguaggi formali) dalla conformità di elementi isolati, ma dalla conformità fra categorie (hjelmslevianamente: classi paradigmatiche d'unità fra loro sostituibili a un punto determinato della catena sintagmatica)". My translation in the text.

20. Original quotation: "la tendenza continua, maniacale in alcuni soggetti, di scrivere su tutto, in forma patologica. Per alcuni soggetti, tuttavia, può anche trattarsi di una "liberazione", di un bisogno inconscio, non patologico". My translation in the text.

21. The correlation between fabrility and signedness concerns that between "technical-rational behaviour and ritual behaviour" (Gri 2001, 87) and was postulated by anthropolgist Alberto Maria Cirese. If therefore by fabrility we mean the essentially a-semiotic - since totally functional - nature of the daily practices dedicated to survival, by signedness instead we mean that sort of "aura of sense" which imbues ritual practices, that is, those to which some segnic order is associated. This opposite category, which yet has the merit of inducing a reflection which in some ways calls into question a diffuse inclination to that which Augusto Ponzio called pansemioticism, and which certainly may emerge in a purely semiotic context, comes up against some problems since - apart from the most rigorous and physiological corporeality (but, in the end, not even that) the appropriation of the world by means of fabrility is itself attributable to a semiotic domain.

\section{REFERENCES}

Baruchello, G. 2002. Fenomenologia linguistica. Riflessioni su Donald Davidson ed Edmund Husserl. Fenomenologia e società, 1/2002, XXV, 17-39. Turin: Rosenberg \& Sellier.

Boehm, G. 2009. II ritorno delle immagini. In: Pinotti, A. \& Somaini, A. eds. Teorie delle immagini. Milan: Raffaello Cortina Editore.

Boniolo, G. and P. Vidali 2003. Introduzione alla filosofia della scienza. Milan: Bruno Mondadori.

Canonico, A. and G. Rossi 2007. Semi-immortalità. Il prolungamento indefinito della vita. Milan: Lampi di stampa.

Cirese, A. 1984. Segnicità, fabrilità, procreazione. Appunti etnoantropologici. Rome: CISU.

Colm Hogan, P. 2000. Philosophical Approaches to the Study of Literature. Gainesville: University of Florida Press.

Dagostino, M.R. 2006. Cito dunque creo. Forme e strategie della citazione visiva. Rome: Meltemi.

Danto, A. 1981. The Transfiguration of the Commonplace. Cambridge, Mass: Harvard University Press.

Decharme, B., V. Safarova, and T. Zemankova 2006. Art Brut: Sbirka abcd. Katalog vystavy usporadane $\checkmark$ Galerii mesta Prahy, Dum u Kamenneho zvonu 14 June -10 September 2006. Prague: Les éditions Abcd.

Fabbri, P. and M. Sbisà 2002. Appunti per una semiotica delle passion. In: Fabbri, P. and G. Marrone, eds. Semiotica in nuce. vol 2. Rome: Meltemi, 237-249.

Freud, Sigmund 1920. Beyond the Pleasure Principle. SE 18: 7-64.

Gri, G.P. 2001. Altri modi: etnografia dell'agire simbolico nei processi friulani dell'inquisizione, Trieste: Edizioni Università di Trieste. 
Intilla, F. 2006. La Funzione d'onda della realtà. L'eterno collasso delle aspettative e convinzioni nel processo sintropico, Milan: Lampi di stampa.

Longato, F. 1999. Interpretazione, comunicazione, verità: saggio sul principio di carità nella filosofia contemporanea. Naples: La città del sole.

Lyotard, J.F. 2011 [1971]. Discourse, Figure. Minneapolis / London: University of Minnesota Press.

Marchianò, G. 1992. Natura e artificio nel mondo della vita. Contributi comparativi italo-giapponesi, Siena: Kyoto-Siena Symposium Bilateral Project.

Martinot, S. 2006. Forms in the Abyss. A Philosophical Bridge between Sartre and Derrida. Philadelphia: Temple University Press.

McGinn, L. and W.C. Sanderson 2005. Treatment of Obsessive-Compulsive Disorder. Lanham, MD: Rowman \& Littlefield Publishers.

Peiry, L. 2004. Ėcriture en délire. Milan / Lausanne: Ėditions 5 Continents.

Pigliacampo, R. 2009. Nuovo dizionario della disabilità, dell'handicap e della riabilitazione. Rome: Armando Editore.

Picciau, M. 2007. Il libro d'artista: esperienze di confine. In: Re-lab. Immagini e parole. Seminario sulle scritture. Perugia: Morlacchi Editore.

Ponzio, A. 1976. La semiotica in Italia. Fondamenti teorici. Bari: Dedalo libri.

Rosenkranz, K. 1853. Aesthetik des Hässlichen. Konigsberg: Verlag der Gebruder Borntraeger. https:// archive.org/details/aesthetikdeshss01rosegoog

Sala, N. and G. Cappellato 2004. Architetture della complessità. La geometria frattale tra arte, architettura e territorio. Milan: Franco Angeli.

Simongini, R. 2012. L'arte ama nascondersi. Limena: Libreria universitaria edizioni.

Spirito, G. 2007. Antonino Terranova. Dalle figure del reale. Risignificazioni e progetti, Rome: Gangemi. Tedesco, S. 2008. Forme viventi. Antropologia ed estetica dell'espressione. Milan / Udine: Mimesis.

Tosatti, B. 1997. Figure dell'anima. Arte irregolare in Europa, Milan: Mazzotta.

Bruno Surace is a Ph.D candidate in Semiotics and Media at the Department of Philosophy and Education Sciences, University of Turin.

Email: b.surace@unito.it 